\title{
Green Shipbuilding and Recycling: Issues and Challenges
}

\author{
Aevelina Rahman and Md. Mashud Karim
}

\begin{abstract}
Shipbuilding industry is one of the hardest metal industries with several chemical and hazardous material exposures. Most of the traditional production processes such as welding, painting, blasting and fiberglass production have direct impacts on workers' health and safety as well as adverse effects on environment. A huge volume of wastes and pollutants is being released during shipbuilding and repairing processes which poses major risk on human health and environmental quality. Thus, this article highlights the current issues and challenges of green shipbuilding and recycling and also encompasses some initiatives and measures. This article is based on a comprehensive literature review related to the issues of green shipbuilding and recycling. The review discussed various aspects of green shipbuilding technology in order to green the industry through ensuring environment protection by reducing environmental pollution in ship manufacturing, service and breaking up. It is found that green shipbuilding and ship recycling contribute to minimize threats on human health, environmental and resource risks by reducing the pollution to air, water and soil; save resources; and improve economic and social benefits. Hence, several initiatives of green shipbuilding and recycling by the International Maritime Organization (IMO) and other shipping industry players have also been discussed.
\end{abstract}

Index Terms-Green recycling, green shipbuilding, issues and challenges, pollution reduction, save resources.

\section{INTRODUCTION}

As the world reels from the impact of various environmental breakdowns, industries are required to play their role to reduce the negative impacts and disturbances to nature. The shipping industry is no exception; being a transport mode that facilitates much of global trade and key to the offshore oil and gas industry, shipping industry is also feeling the pressure to clean up its act and take actions to contribute to a cleaner environment [1]. Due to the rapid and positive change of economic growth, the shipbuilding industry has been growing fast that resulted to increase the work load of shipyards (where ships are built and repaired). Shipyards are categorized into two main types: Shipbuilding and ship repairing. New ship construction and ship repairing have many industrial processes such as cutting, surface treatment, blasting, painting and coating, solvent cleaning and degreasing, welding and fiberglass manufacturing [2]. A huge volume of wastes and pollutants is being released during shipbuilding and repairing processes which pose major risk on human health and environmental quality. These wastes can

Manuscript received November 1, 2014; revised January 5, 2014.

The authors are with the Department of Naval Architecture and Marine Engineering, Bangladesh University of Engineering and Technology (BUET), Dhaka-1000, Bangladesh (e-mail: aevelina2010@gmail.com). be grouped as particulates; volatile organic compounds (VOC's) such as styrene, acetone, methylene, chloride and so on; metal mists and fumes; paint chips; cleaning and paint stripping solvents; oil residues from bilge and cargo tanks; emulsified lubricating and cutting oils; coolants as wastewater and paint chips (containing metals, tributyl-tin); spent abrasives; surface contaminations and cargo tank residues; spent plating solutions and cyanide solutions; waste cutting oil and lube oils as the residual wastes [2].

Shipbuilding industry is known as one of the hardest metal industries with several chemical and hazardous material exposures and is termed as a high energy consumption, high material consumption and high pollution industry. However, green shipbuilding and ship recycling could contribute to minimize human and environmental risks by reducing the pollution to air, water and soil; save resources; and improve economic and social benefits. Hence, several initiatives have been undertaken to "green" the industry by the international maritime organization (IMO) supported by the shipping industry players. Thus, this paper highlights the current issues and challenges of green shipbuilding and recycling and also encompasses the initiatives to be undertaken.

\section{CONCEPT OF GREEN SHIPBUILDING}

Green shipbuilding aims to minimize the offal and harmful emissions during design, manufacturing, service and laying up in order to reduce the pollution to air, water and soil, save resources and improve economic and social benefits [3]. The scope of green shipbuilding includes "green ship" and "green ship yard". Green ship mainly depends on green design in which ships should be designed to enable them give the minimal effect on the environment during manufacturing and service [3]. The keys to green design are 3R:

1) Reduce the consumption of materials and energy and the pollution to environment in ship manufacturing and service;

2) Recycle the parts and accessories in ship maintenance;

3) Reuse the majority of materials after ship laying up.

On the other hand, green shipyard should ensure the high efficiency of materials and energy in shipbuilding, reduce the harmful emissions and smoothen the process of integrated hull construction, outfitting and painting.

\section{ISSUES AND CHALLENGES OF GREEN SHIPBUILDING TECHNOLOGY AND RECYCLING}

This section discusses various aspects of green shipbuilding technology as well as its related issues and challenges in order to green the industry through ensuring 
environment protection by reducing environmental pollution in ship manufacturing, service and breaking up.

\section{A. Selection of Marine Equipment}

There are many types of marine equipment used in the shipbuilding industry for example fuel, propulsion system, materials, engines etc. To promote green shipbuilding technology and recycling, selection of marine equipment should focus the following important issues [3]:

1) Low energy consumption,

2) Low pollution and high efficiency.

3) Evaluation of technical index of ships,

4) Rationality of load factor of main engine, generator, boiler, air condition system, etc.

5) Effective control of harmful emissions, vibration and noise.

The above issues can be fulfilled by the following measures:

- Use of Alternate Fuels

The increasing demand for clean fuel sources in the marine industry has led to the growing demand of alternatives for fuelling. Some aspects of the growing need for alternate fuels are:

1) Conventional marine fuel, also known as bunker fuel is the heavy distillate product obtained after vacuum distillation process in refineries. A large percentage of this fuel is diesel which is thick and heavy.

2) Conventional marine fuel contains sulphur and nitrogen compounds which negatively impact the environment.

3) Several emission controlled areas (ECA's) have been declared which are the Baltic Sea, the North Sea, the North American ECA, including most of US and Canadian coast and the US Caribbean ECA as of 2011, defined by Annex VI of the 1997 MARPOL (Marine Pollution, International Convention for the Prevention of Pollution from Ships) Protocol which came into effect in May 2005. Special environmental considerations exist in these areas [4]. The maximum sulphur content in fuel burnt in such designated areas will drop from $1 \%$ to $0.1 \%$ in recent time.

4) This change will be wide-reaching; around $80-90 \%$ of merchant vessels will enter an ECA in their lifetime.

5) Failing to adapt to the change could be expensive; the cost of low-sulphur fuel that is compliant with regulation is stated to be up to $30 \%$ higher than the price of standard bunker fuel.

Hence, choosing the most cost-effective way to reduce air emissions is vital. Three main alternatives are switching to low-sulphur fuels; installing exhaust after-treatment devices, e.g. scrubbers; and using alternative fuels such as liquefied natural gases (LNG), methanol and di-methyl ether and low sulfur bunker fuel.

- Electric Propulsion System

Electric propulsion system brings about revolutionary changes to ship design, construction, service and maintenance. Fig. 1 shows a schematic diagram of electric propulsion system where batteries along with propulsion motor does the propulsion job. Compared to the conventional propulsion system, the ships with electric propulsion system have a number of advantages. They are:
1) Excellent Handling facility, good maneuvering characteristics.

2) Low vibration and noise level.

3) High reliability-Several parallel main generators supply power with high redundancy and improved reliability of power supply.

4) Small volume-Light weight and flexible arrangement. The ships with electric propulsion system are equipped with middle-high speed diesel generator set of small volume and light weight, cancel gear box and long shafting, etc., general arrangement is flexible and convenient and easy to enlarge loading capacity.

5) High efficiency-Quantity of diesel generators can be automatically controlled by electric power managing system according to the load to ensure the optimal load condition of the diesel generators. It improves the efficiency of generator set greatly and saves the energy.

6) Reducing maintenance-Middle-high speed generator set of the same model needs less maintenance and maintenance cost.

The only challenge of ships with electric propulsion system is that it needs higher construction investments than ships with conventional diesel generators. Despite of this challenge, based on the above mentioned benefits and low ship operating expense, ships with electric propulsion system have been widely recognized and given priority to be selected.

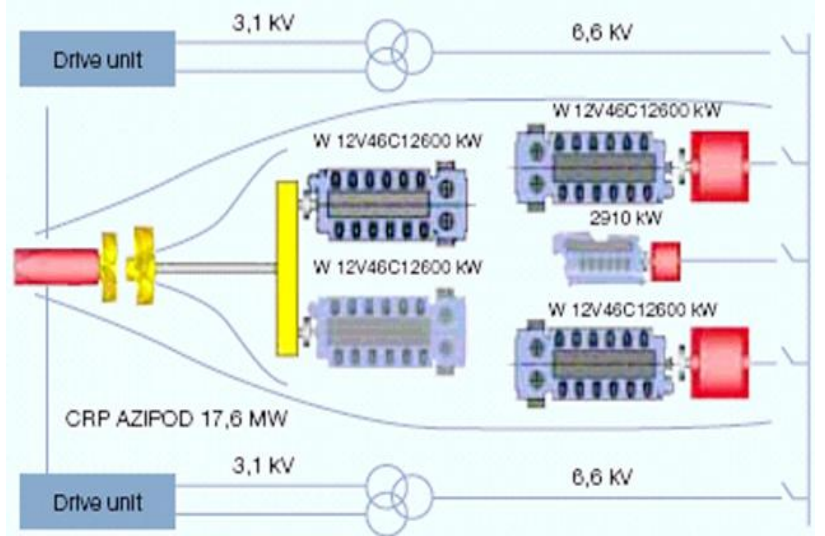

Fig. 1. Schematic diagram of electric propulsion system, source: Hong He-Ping [3].

\section{- Hybrid Propulsion System}

Recently DNV GL (merger between classification societies Det Norske Veritas and Germanischer Lloyd) presented the specific battery hybrid propulsion system and its benefits for the offshore supply vessel Viking Lady at the Greener Shipping Summit - Ships of the Future conference held in Athens. According to Kakalis [5], "considering that the global fleet of offshore supply vessels of relevant sizes is over 4,000 , such technologies have the potential to make an impact when it comes to improving sustainability". The Viking Lady uses a conventional diesel-electric propulsion system, comprising four dual-fuel engines driving five thrusters for propulsion and maneuvering/dynamic positioning where a lithium-ion battery with a capacity of 450 $\mathrm{kWh}$ was added - enabling the vessel to use hybrid-electric propulsion. The battery acts as an energy buffer that is able to cover the intense load variations that can occur, especially in dynamic positioning and standby operations. 
Fig. 2 shows a schematic diagram of a hybrid propulsion system with comprising electric motors, batteries and a generator. The main features and advantages of hybrid propulsion system by which the battery hybrid installation has been tested in sea trials which show [6].

1) A 15 per cent reduction in fuel consumption,

2) 25 per cent reduction in NOx emissions, and

3) 30 per cent reduction in GHG emissions can be realized in practice, especially for dynamic positioning operations.

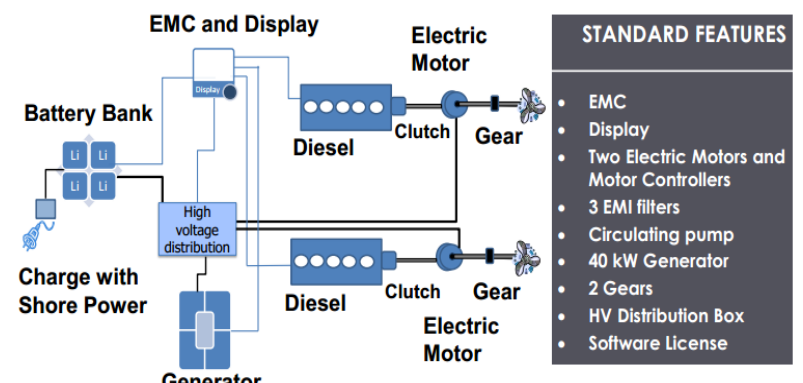

Fig. 2. Hybrid propulsion system, source: Regen Nautic [7].

\section{B. Optimization of Marine System}

Optimization is another popular greening approach in the shipbuilding industry. The optimization of marine system design should lay stress on saving materials, increasing work efficiency and decreasing cost. To emphasize the concept of green ship design, the following methods can be applied to optimize design:

1) The optimization of hull lines will increase ship speed, save energy and improve economic efficiency.
2) The optimization of hull structure will decrease the specification of steel and the light weight of vessel, increase the deadweight and improve economic efficiency.

3) The optimization of piping system design will decrease the length of pipes and quantity of pipe bends.

4) The optimization of electric system design will decrease the length of cables, decrease the quantity of equipment and increase the quantity of section pre- fabrication.

5) The module design or unit design will carry out diffusion production and parallel working of intermediate products and increase pre-outfitting ratio, assembly ability and work efficiency.

\section{Selection of Materials}

The selection of green materials is very important to green shipbuilding. In the selection of materials, the emphasis should be given to the following issues [3]:

1) Innocuous, inoffensive and environment materials.

2) Materials convenient for reclaiming and materials which can be recycled.

3) Decrease the quantity of variety and specification of materials to improve the utilization ratio.

4) Decrease the weight of materials to increase the ship loading capacity.

\section{Improvement of Building Technique}

Adjustment and hence improvement from traditional building techniques has a significant impact to greening the shipping industry. Table I summarizes a list of possible improvement in traditional building techniques.

TABLE I: LIST OF POSSIBLE IMPROVEMENT IN BUILDING TECHNIQUES

\begin{tabular}{l|l}
\hline Welding technology & $\begin{array}{l}\text { Innovation and application of high efficient welding technology will increase work efficiency, save energy and } \\
\text { slow down pollution. }\end{array}$ \\
\hline $\begin{array}{l}\text { Hull construction with } \\
\text { outfitting and painting }\end{array}$ & $\begin{array}{l}\text { The integration of hull construction with outfitting and painting and innovation and application of ship painting } \\
\text { technology will increase work efficiency, save energy, decrease waste, slow down pollution and carry out } \\
\text { integrated hull construction, outfitting and painting. }\end{array}$ \\
\hline Module and unit technology & $\begin{array}{l}\text { Innovation and wide application of module and unit technology will realize extended manufacturing and } \\
\text { parallel working of interim products to improve work efficiency. }\end{array}$ \\
\hline $\begin{array}{l}\text { Super block lifting } \\
\text { technique }\end{array}$ & $\begin{array}{l}\text { Application of super block lifting technique of integrated accommodation, engine room, bow, stern and pump } \\
\text { room, etc. will realize extended manufacturing and parallel working of interim products to improve work } \\
\text { efficiency and save energy }\end{array}$ \\
\hline $\begin{array}{l}\text { Hull accuracy control } \\
\text { technology }\end{array}$ & $\begin{array}{l}\text { Application of hull accuracy control technology, including no-tolerance lifting of blocks, expanding } \\
\text { no-tolerance laying-off, increasing the accuracy of block manufacturing, effectively controlling the deviation of } \\
\text { hull principle dimensions will improve work efficiency, save energy and decrease pollution and waste. }\end{array}$ \\
\hline Secondary steel nesting & $\begin{array}{l}\text { Application of secondary steel nesting technology to carry out optimized design, elaborate nesting and to } \\
\text { improve the secondary utilization ratio of steel will save steel materials and decrease waste }\end{array}$ \\
\hline Source: Hong He-Ping [3] &
\end{tabular}

\section{E. Life Cycle Assessment}

Life cycle assessment (LCA) is a technique to assess environmental impacts associated with all the stages of a ship's life from raw material extraction through materials processing, manufacture, running life, repair and maintenance, and disposal or recycling. LCA can help to avoid a narrow outlook on environmental concerns by compiling an inventory of relevant energy and material inputs and environmental releases; evaluating the potential impacts associated with identified inputs and releases; and interpreting the results to help make a more informed decision. Fig. 3 demonstrates life cycle assessment in relation to ships and how LCA can play a vital role in establishing a green ship industry.

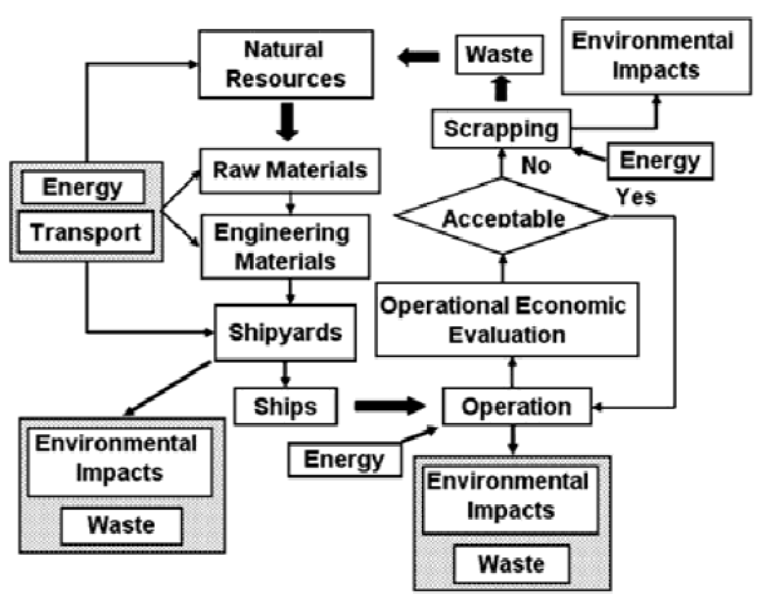

Fig. 3. Life cycle assessment of a ship, source: Umweltschutz and Seeverkehr [8]. 


\section{F. Ship Recycling}

Recycling makes a positive contribution to the global conservation of energy and resources and, in the process, employs a large, if predominantly unskilled, workforce. Properly handled, ship recycling plays an important role in green shipping industry. In the process of recycling ships, some of the benefits are given below:

1) The materials and equipment are almost entirely reused.

2) Steel is reprocessed to become, for instance, reinforcing rods for use in the construction industry or as corner castings and hinges for containers.

3) Ships' generators are reused ashore. Batteries find their way into the local economy.

4) Hydrocarbons on board become reclaimed oil products to be used as fuel in rolling mills or brick kilns.

5) Light fittings find further use on land.

6) Furthermore, new steel production from recycled steel requires only one third of the energy used for steel production from raw materials.

\section{IMO: ENVIRONMENT FRIENDLY MEASURES AND INITIATIVES}

In the early days of sailing ships, lime and later arsenic were used to coat ships' hulls, until the modern chemicals industry developed effective anti-fouling paints using metallic compounds. These compounds persist in the water; kills sea life; harms the environment and enters the food chain. One of the most effective anti-fouling paints, developed in the 1960s, contains the organotin tributylin (TBT), which has been proven to cause deformations in oysters and sex changes in whelks. The adoption of the new Convention called on States to take measures to reduce pollution caused by organotins compounds used in anti-fouling systems. IMO's Marine Environment Protection Committee (MEPC) adopted a resolution which recommended that Governments adopt measures to:

1) Eliminate the use of anti-fouling paint containing TBT on non-aluminium hulled vessels

2) Eliminate the use of anti-fouling paints with a leaching rate of more than four micrograms of TBT per day.

The Hong Kong International Convention for the Safe and Environmentally Sound Recycling of Ships, 2009 (the Hong Kong Convention)[9], was adopted at a diplomatic conference held in Hong Kong, China, from 11 to 15 May 2009, which was attended by delegates from 63 countries. The Convention is aimed at ensuring that ships, when being recycled after reaching the end of their operational lives, do not pose any unnecessary risks to human health, safety and to the environment. The Hong Kong Convention [9] covers the following regulations in relation to the ship recycling:

1) The design, construction, operation and preparation of ships so as to facilitate safe and environmentally sound recycling without compromising the safety and operational efficiency of ships;

2) The operation of ship recycling facilities in a safe and environmentally sound manner;

3) The establishment of an appropriate enforcement mechanism for ship recycling, incorporating certification and reporting requirements.

4) Upon entry into force of the Hong Kong Convention, ships to be sent for recycling will be required to carry an inventory of hazardous materials, which will be specific to each ship.

5) An appendix to the Convention provides a list of hazardous materials the installation or use of which is prohibited or restricted in shipyards, ship repair yards, and ships of Parties to the Convention.

6) Ships will be required to have an initial survey to verify the inventory of hazardous materials, additional surveys during the life of the ship, and a final survey prior to recycling.

7) Ship recycling yards will be required to provide a "Ship Recycling Plan", specifying the manner in which each ship will be recycled, depending on its particulars and its inventory.

8) Parties will be required to take effective measures to ensure that ship recycling facilities under their jurisdiction comply with the Convention.

\section{GREEN SHIP OF THE FUTURE}

Green Ship of the Future is a cooperation in which companies across the Danish maritime industry joined forces in order to develop strategies to reduce $\mathrm{CO}_{2}$ by $30 \%, \mathrm{SO}_{x}$ by $90 \%$ and $\mathrm{NO}_{\mathrm{x}}$ by $90 \%$ [10]. Table II shows selected technologies for the 35,000 DWT Handy size Bulk Carrier concept study to evaluate the effect on emissions, fuel consumption, space requirement, budget costs and cargo intake for this ship design if all these technologies were included:

TABLE II: Additional PuRchase PRICE For ConcePt SHIP Due to GREENING MEASURES

\begin{tabular}{l|c}
\multicolumn{1}{c}{ Measure } & $\begin{array}{c}\text { Additional purchase costs } \\
\text { (Thousands of USD) }\end{array}$ \\
\hline $\begin{array}{l}\text { Speed nozzle/optimized } \\
\text { propeller/ME derating }\end{array}$ & 700 \\
\hline $\begin{array}{l}\text { Twisted spade rudder with Costa } \\
\text { bulb }\end{array}$ & 160 \\
\hline Water in fuel (WIF) & 200 \\
\hline Exhaust gas recirculation (EGR) & 600 \\
\hline Waste heat recovery system (WHR) & 1,250 \\
\hline Exhaust gas scrubber & 1,200 \\
\hline $\begin{array}{l}\text { Ducted/direct air intake for main } \\
\text { engine }\end{array}$ & 20 \\
\hline $\begin{array}{l}\text { Optimized coolers and cooling } \\
\text { pumps }\end{array}$ & 150 \\
\hline $\begin{array}{l}\text { Auxiliary engine operation on } \\
\text { marine gas oil (MGO) }\end{array}$ & -- \\
\hline High capacity fresh water generator & 50 \\
\hline $\begin{array}{l}\text { Installation of ballast water } \\
\text { treatment System (BWT) }\end{array}$ & 5,140 \\
\hline & \\
\hline Source: Shipping Freshmaker & \\
\hline
\end{tabular}

Source: Shipping Freshmaker [10]

The ship has not been build, but has been designed with the available technologies already implemented during the design phase. To ensure that the two concept ships fulfil the relevant Class regulations, all calculations and drawings have been 
given a Class Notation. The effect on the annual emission is shown in Table III.

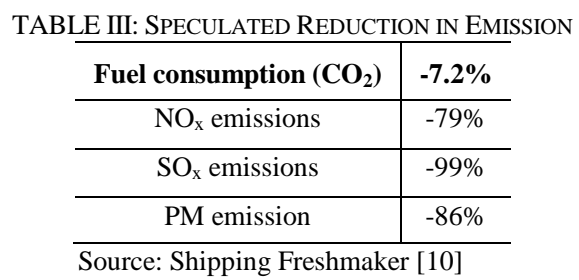

The purchase price of the concept ship was estimated to be $22 \%$ higher ( 5 million USD) than the baseline ship. The yearly operational costs were estimated to be 100,000 USD lower. A speed reduction of about 2 knots would allow for a reduction of $30 \%$ of $\mathrm{CO}_{2}$ emissions.

\section{CONCLUDING REMARKS}

Most of the traditional production processes such as welding, painting, blasting and fiberglass production have direct impacts on workers' health and safety as well as adverse effects on environment. The measures and initiatives of green shipbuilding and recycling will not only be useful to the shipbuilding and marine industry but also be protective to global environment and resource. For example, when LNG is used as a bunker fuel, it ensures that environmental compliances are met and further reduces the risk of engine failure and also meets the sulfur content and emission requirements. Choosing liquefied natural gas as fuel of diesel engine can save $35 \%$ of fuel cost and reduce harmful emission, it is largely better than common diesel oil in environment protection. However, green ship design, building, manufacturing, services, maintenance and recycling and other activities should comply with suggestions or requirements on environment protection of ship classification societies and with the international ship construction conventions, its rules, regulations and standards.

\section{ACKNOWLEDGEMENT}

The authors would like to thank Associate Professor Dr Rawshan Ara Begum from University Kebangsaan Malaysia (UKM) for helping to frame this article.

\section{REFERENCES}

[1] N. Khalid and M. Ang, "From shipyards to the seas: Green features in shipbuilding," The Australian Marine Environment Protection Association, 2010.
[2] L. Bilgili and U. B. Calebi, "An innovative method establishment for a green shipyard concept," in Green Design, Materials and Manufacturing Processes, Taylor \& Francis Group, London, 2013, p. 273.

[3] H. H. Ping, The Trend of Green Shipbuilding Technology, Guangzhou Shipyard International Company Limited, China, 2008.

[4] Prevention of Air Pollution from Ships, Annex VI, 1997 MARPOL Protocol, International Maritime Organization (IMO). (2008). [Online]. Available: http://www.imo.org/

[5] N. Kakalis. (2014). SHIP III research and development project, Research Council, Norway. [Online]. Available: http://www.dnvgl.com.

[6] P. W. Richardsen, DNV GL Innovating to Improve Safety and Efficiency in High Risk Operations, Communication Research and Innovation, DNV GL AS., 2014.

[7] R. Nautic. (2014). Hibrid electric propulsion. [Online]. Available: http://regennautic.com/products/hybrid-power/

[8] G. F. A. Umweltschutz and S. Seeverkehr, Ship Life Cycle Assessment and Management, Hochschule Bremen, University of Applied Science, Bremen, Germany, 2011, ch. 1, p. 6.

[9] Hong Kong Convention, The Hong Kong International Convention for the Safe and Environmentally Sound Recycling of Ships, Hong Kong, China.

[10] Shipping Freshmaker. (2013). Green ship of the future. [Online]. Available:

http://www.cnss.com.cn/html/2013/updates_0708/112690.html

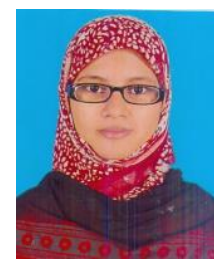

Aevelina Rahman is currently a final year student of the Department of Naval Architecture and Marine Engineering in the Bangladesh University of Engineering and Technology (BUET). She was born in Lvov, Ukraine in 1990. She received outstanding results with Golden GPA (5 out of 5) in the Secondary School Certificate \& Higher Secondary School Certificate examinations from a renowned educational institute in Bangladesh namely Viqarunnisa Noon School and College. She started her engineering study in BUET in 2010. Her research interests are in the areas of green shipbuilding, recycling and environmental issues related to the marine industry.

Ms. Rahman has been consecutively securing a place in the prestigious dean's list of the Faculty of Mechanical Engineering, BUET for her excellent academic performance for the last four years.

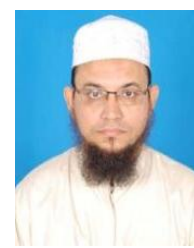

Md. Mashud Karim is currently a professor at the Department of Naval Architecture and Marine Engineering in the Bangladesh University of Engineering and Technology (BUET). He was born in Bangladesh in 1967. He received his $\mathrm{PhD}$ degree in naval architecture and ocean engineering from the Yokohama National University, Japan. His teaching and research interests focus on computational ship geometry, hydrodynamics, resistance \& propulsion, and hydrofoil \& propeller optimization.

He has published more than 40 articles in the refereed international and national journals as well as conference proceedings.

Dr. Karim is an associate member of the Society of Naval Architects and Marine Engineers (SNAME), USA and life member of the Association of Naval Architects and Marine Engineers (ANAME), Bangladesh. 